\title{
Association of Herbicides for Management of Weed Plants in Pre-emergence of Soybean Culture
}

\author{
Carlos Orestes Santin ${ }^{1}$, Everton Giacomin ${ }^{2}$, Leandro Galon ${ }^{1}$, André Dalponte Menegat ${ }^{1}$, \\ Emanuel Rodrigo de Oliveira Rossetto ${ }^{1}$, Milena Barretta Franceschetti ${ }^{1}$, Maico André Michelon Bagnara ${ }^{1}$, \\ Antônio Marcos Loureiro da Silva ${ }^{1}$, Rodrigo José Tonin ${ }^{1}$, Leonardo Brunetto ${ }^{1} \&$ César Tiago Forte ${ }^{3}$ \\ ${ }^{1}$ Agronomy Department, Universidade Federal da Fronteira Sul, Erechim, Brazil \\ ${ }^{2}$ Agronomy Department, Universidade do Oeste de Santa Catarina, Xanxerê, Brazil \\ ${ }^{3}$ Agronomy Department Universidade de Santa Maria, Santa Maria, Brazil \\ Correspondence: César Tiago Forte, Agronomy Department, Universidade de Santa Maria, Santa Maria, Brazil. \\ Tel: 55-549-9688-9706. E-mail: cesartiagoforte@hotmail.com
}

Received: November 29, 2018

doi:10.5539/jas.v11n4p217
Accepted: January 7, $2019 \quad$ Online Published: March 15, 2019

URL: https://doi.org/10.5539/jas.v11n4p217

\begin{abstract}
One of the big challenges to the soybean cultivation is the control of weed plants, because of the competitive potential that they presente and the resistance index in relation to the herbicides. In front of this, the work had as objective to evaluate the mix of herbicides in tanks to initial control of weed plants in the soybean culture. The experiment was installed in field in sistem of no-tillage in an área that presented the cultute of the wheat as precedente. The design used was that one of randomized blocks, with four repetitions. The herbicide's treatments used in the test were: glyphosate, glyphosate + (diuron+sulfentrazone), glyphosate + diclosulam, glyphosate + (imazethapyr + flumioxazin), glyphosate + flumioxazin, glyphosate $+2,4-\mathrm{D}$, glyphosate + S-metolachlor, amônio-glufosinate + (diuron + sulfentrazone). The variable used was phytotoxicity in the culture, weed plants' control Urochloa plantaginea and Raphanus sp., thousand grains weight and productivity of the soybean. The data were submitted to analysis of variance by the F test and the compared averages by the Scott-Knott test, in $5 \%$ of error probability. The phytotoxicity caused by the herbicides in the culture is not significative in the point of decrease the grains yield. The herbicides that presented better control of $U$. plantaginea were the associations of glyphosate with diuron + sulfetrazone, imazethapyr + flumioxazin and s-metolaclhor. Already in the control of Raphanus sp., the association of diclosulam and imazethapyr + flumioxazin with glyphosate presents results next of $100 \%$ of control. The variable thousand grains weight it was not affected by the association of the herbicides. In relation to the soybean grains productivity the herbicides (glyphosate + diclosulam and glyphosate + (imazethapyr + flumioxazin)) that provide low phytotoxicity and high control of the weed plants had their productivity compared to the weeded control.
\end{abstract}

Keywords: Urochloa plantaginea, Raphanus sp., mix in tank

\section{Introdution}

The soybean culture has big importance in the world stage, it is the base of the human and animal eating, reflecting directly in the economy (Miransari et al., 2016). In the world the soybean, represent a semeated area of 126 millions of hectares, with a total production of 348 millions of tons. The USA is the biggest world produtor of soybean and Brazil occupy the second place in the ranking, with production estimate of 108 million of tons, corresponding to approximately 35 million of hectares (USDA, 2018). The oil and the bran are the mainly subproducts of the soybean, more recently the researches elevate the soybean as a renewable source of material to the industry and will turn into the mainly fount of proteins to human beings and animals (Liu, 2016; Miransari, 2016).

In the initial stages of the stablishment of the culture is the moment when occurs a good part of the definition of the productivity, besides of the loses in the initial stages because of the competition of the weed plants for environmental resources, the improper handling of these species can unfeasible the harvest proccess (Agostinetto et al., 2015). 
Among the weed plants that presentes high competitive ability with the soybean and interferes significantly in the quality and in the quantity of the producted grains, the species Raphanus sp. causes competition in the initial stages, because of the fact that occurs its resemination after its stablishment in the cold period, being possible to occur reduction in the leaf area of the soybean (Fleck et al., 2006). Urochloa plantaginea is another species that infest the soybean culture, it is a grassy that presentes C4 metabolism, and it is substantially cespitosa, compeating manly for the light (Agostinetto et al., 2009).

The control of weed plants can be done in many ways, one of the alternatives is the chemical control. Inside the method the association of herbicides with diferente mechanisms of action, besides of provides a prolonged control, decrease the probability of the weed plants get resistance (Westwood et al., 2017; Braz et al., 2017).

The glyphosate is very used in the desiccation, before of the seeding of the culture, it is effective to some species of weed plants, however in the presente has growing up the increase of the cases of resistance of weed plants, the association of glyphosate with herbicides of bigger residual presents bigger results in the control of weed plants and decrease the probability of resistance of these species (Jaremtchuk et al., 2008; Arregui et al., 2006; Dominguez-Valenzuela et al., 2017; Westwood et al., 2018).

The difficulty in find herbicides that present residual and don't cause phytotoxicity to the culture, has been motive of many studies. The herbicide flumioxazin, in research, was observed that presents phytotoxicity in Young plants, however being characterized as few injurious in the productivity of the soybean culture (Grichas et al., 2009; Kandel et al., 2018). The herbicide glyphosate combined with diuron + sulfentrazone and flumioxazin and amônio-glufosinato + diurom + sulfentrazone present low efficiency in the controlo $f$ some weed plants when compared with, association of glyphosate + sulfentrazone in which presents good control in $U$. plantaginea and Digitaria ciliares, however in dicotyledoneous plants don't present satisfactory control, already diclosulam presents satisfactory control in dicotyledoneous, when applied in pre-emergency not influiyng in the soybean grains productivity (Nonemacher et al., 2017; Braz et al., 2017).

To species of weed plants that presents resistance or tolerance to the herbicide glyphosate the utilization of pre-emergents herbicids turn into an alternative, decreasing the competition of weed plants in the beggining of the season of growing of the soybean plants, being the association of herbicides an alternative to weed plants control with resistance historic (Arregui et al., 2006; Westwood et al., 2018; Braz et al., 2017).

The hypothesis of the present research is that the association of herbicides in mix tanks with glyphosate cause bigger control of weed plants, keeping residual in the ground and don't interferes in the yield of the soybean culture. Therefore, the objective of the study it was to evaluate association of herbicides to the control of weed plants in pre-emergency of soybean culture.

\section{Material and Methods}

The experiment was installed in field in the experimental area of Universidade Federal da Fronteira Sul (UFFS), Campus Erechim/RS, in the year of 2017, in the system of no-tillage in an área that presented the soybean culture as precedent. The soil of the place of conduction was classified as Rhodic Hapludox (Soil Survey Staff, 2014), the chemical and fisical caracteristics of the soil were: $\mathrm{pH}$ in water of $4.8 ; \mathrm{O} . \mathrm{M} .=3.5 \% ; \mathrm{P}=4.0 \mathrm{mg} \mathrm{dm}^{-3}$; $\mathrm{K}=117.0 \mathrm{mg} \mathrm{dm}{ }^{-3} ; \mathrm{Al}^{3+}=0.6 \mathrm{cmolc} \mathrm{dm}{ }^{-3} ; \mathrm{Ca}^{2+}=4.7 \mathrm{cmolc} \mathrm{dm}^{-3} ; \mathrm{Mg}^{2+}=1.8 \mathrm{cmolc} \mathrm{dm}{ }^{-3} ; \mathrm{CTC}(\mathrm{t})=7.4 \mathrm{cmolc}$ $\mathrm{dm}^{-3} ; \mathrm{CTC}(\mathrm{TpH}=7.0)=16.5 \mathrm{cmolc} \mathrm{dm}^{-3} ; \mathrm{H}+\mathrm{Al}=9.7 \mathrm{cmolc} \mathrm{dm}^{-3} ; \mathrm{SB}=6.8 \mathrm{cmolc} \mathrm{dm}^{-3} ; \mathrm{V}=41 \%$; and Clay $=$ $60 \%$, being that before of the seeding it was effected the correction of the fertility following the technical recommendation to the soybean culture (ROLAS, 2016).

In the Figure 1 it is possible to observe the prognosis of the rainfall and daily average temperature in the elapse of the culture cicle (INMET, 2018). 


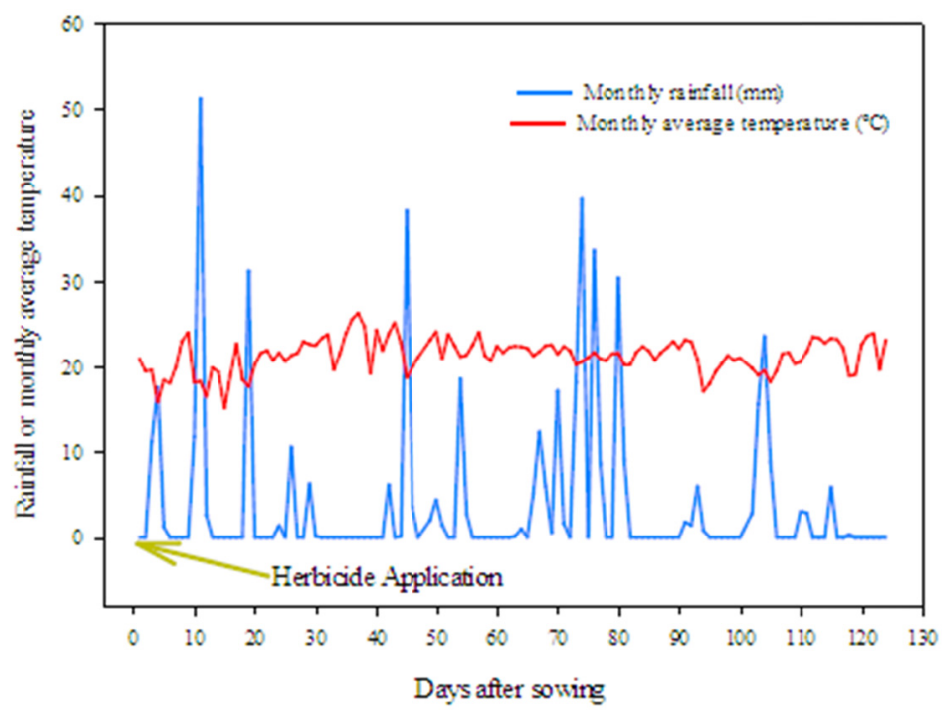

Figure 1. Rainfall (mm) and monthly average temperature $\left({ }^{\circ} \mathrm{C}\right)$ in the period of cultivation of the soybean, cycle of 124 days (INMET, 2018)

The design used was that one of causalized blocks, with four repetitions. The herbicides, concentrations, doses, the company that owns the product and the time of application of the treatments used in the experiment are described in Table 1.

Table 1. Detailing of the treatments used with their respective doses and time of application of the treatments

\begin{tabular}{|c|c|c|c|c|}
\hline Tratamentos & $\begin{array}{l}\text { Dose } \\
\left(\mathrm{g} \mathrm{ha}^{-1}\right) \text { i.a. ou e.a. }\end{array}$ & $\begin{array}{l}\text { Dose } \\
(\text { L or kg ha-1) C.P. }\end{array}$ & $\begin{array}{l}\text { Adjuvant } \\
(0.5 \% \mathrm{v} / \mathrm{v})\end{array}$ & Application time \\
\hline Unweeded control & - & - & - & - \\
\hline Weeded control & - & - & - & $\ddot{-}$ \\
\hline Glyphosate & 1440 & 3.0 & Mineral oil & Desiccation \\
\hline \multirow{2}{*}{ Glyphosate $+($ Diuron + sulfentrazone $)$} & 1440 & 3.0 & \multirow{2}{*}{ Mineral oil } & Desiccation \\
\hline & 735 & 1.4 & & Pre-emergence* \\
\hline \multirow{2}{*}{ Glyphosate + Diclosulam } & 1440 & 3.0 & \multirow{2}{*}{ Mineral oil } & Desiccation \\
\hline & 25.2 & 0.03 & & Pre-emergence \\
\hline \multirow{2}{*}{ Glyphosate + (Flumioxazin + imazethapyr $)$} & 1440 & 3.0 & \multirow{2}{*}{ Mineral oil } & Desiccation \\
\hline & 150 & 0.5 & & Pre-emergence \\
\hline \multirow{2}{*}{ Glyphosate + Flumioxazin } & 1440 & 3.0 & \multirow{2}{*}{ Mineral oil } & Desiccation \\
\hline & 50 & 0.1 & & Pre-emergence \\
\hline \multirow{2}{*}{ Glyphosate $+2,4-\mathrm{D}$} & 1440 & 3.0 & \multirow{2}{*}{ Mineral oil } & Desiccation \\
\hline & 806 & 1.0 & & Pre-emergence \\
\hline \multirow{2}{*}{ Glyphosate + S-metolachlor } & 1440 & 3.0 & \multirow{2}{*}{ Mineral oil } & Desiccation \\
\hline & 1440 & 1.5 & & Pre-emergence \\
\hline \multirow{2}{*}{ Amonio-glufosinate (Diuron + sulfentrazone) } & $400^{-1}$ & 2.0 & \multirow{2}{*}{ Mineral oil } & Desiccation \\
\hline & 735 & 1.4 & & Pré \\
\hline
\end{tabular}

Note. *Pre-emergence: Herbicide application in pre-emergence of soybean and weed crops. i.a.: active ingredient. e.a.: acid equivalent. C.P.: commercial product.

Each experimental unity was characterized by a parcel of $15 \mathrm{~m}^{2}(5 \times 3 \mathrm{~m})$ seed with 6 lines of soybean in spacing of $0.5 \mathrm{~m}$. The mainly weed plants present in the experimental area were the Urochloa plantaginea and Raphanus sp., in the medium densities of 133 and 45 plants $\mathrm{m}^{-2}$, respectively. The application of the herbicides was performed with precision costal sprayer, pressurized in $\mathrm{CO}_{2}$, equipped with four spray tips kind fan DG 
110.02 , keeping constant pressure of $210 \mathrm{kPa}$ and displacement velocity of $3.6 \mathrm{~km} \mathrm{~h}^{-1}$, what provides the flow rate of $150 \mathrm{~L} \mathrm{ha}^{-1}$ of herbicide syrup.

The phytotoxicity caused by herbicides the soybean cultivation Nidera 5909 was evaluated in the $07,14,21$ and 28 days after the treatments applications (DTA), in the same way that was realized the evaluation of the weed plants control. Attributes percentual grades, in which zero $(0 \%)$ represented absent of phytotoxicity to the soybean, or with absent of weed plants control and the grade of one hundred $(100 \%)$ to the complete death of the culture or of the weed plants, according to the methodology of SBCPD (1995).

The harvest of the soybean was realized when the grains reached $16 \%$ of moisture, through of the plants track in useful area of $3.0 \mathrm{~m}^{2}$ by experimental unity. From the track was determined the one thousand grain weight (g), being counted 8 samples of 100 grains each and weighing the same in analytical balance. Then it was estimated the productivity of grains adjusting to $13 \%$ of moisture, extrapolated to $\mathrm{kg} \mathrm{ha}^{-1}$.

The data was submitted to the analysis of variance by the F test, and, in being significant, the averages were compared by the test of multiple comparison of Scott-Knott in $\mathrm{p} \leq 0.05$.

\section{Results and Discussion}

To the phytotoxicity of the culture of the soybean occurred difference in the 7 and 14 DTA, mainly to herbicides applied in association with glyphosate, diuron + sulfentrazone, diclosulam, imazethapyr + flumioxazin and diuron + sulfentrazone (Table 2). However, the phytotoxicity found don't overcome the 7\%, characterizing itself as association little harmful to the culture, when applied in pre-emergency, in research realized with the herbicide herbicide flumioxazin was observed phytotoxicity in the young plants, however it don't affect the productivity of soybean grains (Grichas et al., 2009).

After the period of 21 DTA the effect of the herbicides in associations don't present visual symptoms of phytotoxicity (Table 2). Results that corroborate with studies of Kandel et al. (2018), the herbicides flumioxazin, sulfentrazone and S-metalachlor even associate to other herbicides, rarely the authors observed phytotoxicity in the stage V4 (4 developed leafs).

Table 2. Phytotoxicity (\%) of soybean culture in function of application of different associations of herbicides applied in the pre-emergency of the culture

\begin{tabular}{lllll}
\hline \multirow{2}{*}{ Treatment } & \multicolumn{3}{c}{ Phytotoxicity (\%) } \\
\cline { 2 - 5 } & 07 DTA & 14 DTA & 21 DTA & 28 DTA \\
\hline Unweeded control & $0 \mathrm{~d}^{*}$ & $0 \mathrm{~b}$ & $0^{\text {ns }}$ & 0 \\
Weeded control & $0 \mathrm{~d}$ & $0 \mathrm{~b}$ & 0 & 0 \\
Gly & $0 \mathrm{~d}$ & $0 \mathrm{~b}$ & 0 & 0 \\
Gly + Diu + Sulf & $4 \mathrm{~b}$ & $3 \mathrm{a}$ & 0 & 0 \\
Gly + Dic & $6 \mathrm{a}$ & $3 \mathrm{a}$ & 0 & 0 \\
Gly + Imaz + Flum & $7 \mathrm{a}$ & $3 \mathrm{a}$ & 0 & 0 \\
Gly + Flum & $2 \mathrm{c}$ & $0 \mathrm{~b}$ & 0 & 0 \\
Gly + 2,4-D & $0 \mathrm{~d}$ & $0 \mathrm{~b}$ & 0 & 0 \\
Gly + S-met & $2 \mathrm{c}$ & $0 \mathrm{~b}$ & 0 & 0 \\
Glu + Diu + Sulf & $3 \mathrm{~b}$ & $4 \mathrm{a}$ & 0 & $\mathbf{0 . 0 0}$ \\
\hline C.V. (\%) & $\mathbf{5 0 . 9 6}$ & $\mathbf{4 6 . 0 8}$ & $\mathbf{0 . 0 0}$ & 0 \\
\hline
\end{tabular}

Note. * Significant error probability of $0.05 .{ }^{\text {ns }}$ don't significant. Gly: glyphosate, Diu: diuron, Sulf: sulfetrazone, Dic: diclosulan, Imaz: Imazethapyr, Flum: flumioxazim, 2,4-D, S-met: S-metolachlor.

At 7 DTA the herbicides that had the best $\%$ of control of $U$. plantaginea were the associations with sulfentrazone, herbicide this that is indicated mainly to the control of monocotyledons (Table 3). The sulfentrazone presents satisfactory results in the control of $U$. plantaginea and $D$. ciliares in the culture of soybean (Nonemacher et al., 2017) and Oryza sativa involuntary in the cuture of rice (Singh et al., 2016), proving its high efficiency in the control of narrow leaf species.

Besides these herbicides it is noticed that in the 14 DTA the associations of glyphosate with imazethapyr + flumioxazin and S-metolaclhor also had satisfactory control of $U$. plantaginea, equating with the best associations of 7 DTA (Table 3). Already the association of glyphosate only with flumioxazin observes the worst 
results in the control of $U$. plantaginea. Studies show low efficiency of flumioxazin in species of the same gender, even with the application of dose higher than the present work (Grichar et al., 2009).

At the 21 DTA kept satisfactory control with use of sulfentrazone in the associations with glyphosate + diuron and amonio-glufosinate. Already the herbicides diclosuram, glyphosate, flumioxazin and 2,4-D associated or not, they were not efficient in the control of $U$. plantaginea in application, of pre-emergency, this by the fact of being herbicides with low efficiency in the control of monocotyledons and that present little residual (Rodrigues \& Almeida, 2011).

Table 3. Control of Urochloa plantaginea (\%) in the culture of soybean in function of application of different associations of herbicides in the pre-emergency

\begin{tabular}{lllll}
\hline \multirow{2}{*}{ Treatment } & \multicolumn{4}{c}{ Control of U. plantaginea (\%) } \\
\cline { 2 - 5 } & 07 DTA & 14 DTA & 21 DTA & 28 DTA \\
\hline Unweeded control & $0 \mathrm{~d}$ & $0 \mathrm{c}$ & $0 \mathrm{c}$ & $0 \mathrm{e}$ \\
Weeded control & $100 \mathrm{a}$ & $100 \mathrm{a}$ & $100 \mathrm{a}$ & $100 \mathrm{a}$ \\
Gly & $0 \mathrm{~d}$ & $0 \mathrm{c}$ & $0 \mathrm{c}$ & $0 \mathrm{e}$ \\
Gly + Diu + Sulf & $91 \mathrm{~b}$ & $90 \mathrm{~b}$ & $83 \mathrm{~b}$ & $50 \mathrm{~d}$ \\
Gly + Dic & $0 \mathrm{~d}$ & $0 \mathrm{c}$ & $0 \mathrm{c}$ & $0 \mathrm{e}$ \\
Gly + Imaz + Flum & $73 \mathrm{c}$ & $84 \mathrm{~b}$ & $90 \mathrm{~b}$ & $66 \mathrm{c}$ \\
Gly + Flum & $0 \mathrm{~d}$ & $0 \mathrm{c}$ & $0 \mathrm{c}$ & $0 \mathrm{e}$ \\
Gly + 2,4D & $0 \mathrm{~d}$ & $0 \mathrm{c}$ & $0 \mathrm{c}$ & $0 \mathrm{e}$ \\
Gly + S-met & $70 \mathrm{c}$ & $87 \mathrm{~b}$ & $0 \mathrm{c}$ & $0 \mathrm{e}$ \\
Glu + Diu + Sulf & $94 \mathrm{~b}$ & $86 \mathrm{~b}$ & $89 \mathrm{~b}$ & $97 \mathrm{~b}$ \\
C.V. (\%) & $\mathbf{9 . 1 9}$ & $\mathbf{6 . 2 8}$ & $\mathbf{1 3 . 9 3}$ & $\mathbf{1 9 . 6 6}$ \\
\hline
\end{tabular}

Note. * Significant error probability of $0.05 .{ }^{\text {ns }}$ don't significant. Gly: glyphosate, Diu: diuron, Sulf: sulfetrazone, Dic: diclosulan, Imaz: Imazethapyr, Flum: flumioxazim, 2,4-D, S-met: S-metolachlor.

In associations of herbicides diclosulam and imazethapyr + flumioxazin with glyphosate it is observed that the control of Raphanus sp. was equal the weeded witness, with control next to $100 \%$ (Table 4). The efficiency presented by these combinations is due to the different mechanisms of action, because the frequent utilization of inhibitor herbicides of enzyme ALS, promotes the increase of its activity, consequently the emergency of resistance cases, already described in the literature (Li et al., 2013; Cechin et al., 2016).

Intermediate Controls $(<80 \%)$ was obtained by glyphosate combinated with diuron + sulfentrazone and flumioxazin and the combination of amonio-glufosinato + diuron + sulfentrazone. The sulfentrazone presents good control in U. plantaginea and Digitaria ciliares, already in plants dicotyledons don't present satisfactory control (Nonemacher et al., 2017).

Already the herbicides, diuron + sulfentrazone and flumioxazin associated to glyphosate, don't present satisfactory control after the 7 DTA, however possibly handling doses will can achieve best results in the control of Raphanus sp., that way, future researches can clarify this hypothesis. The herbicide S-metalachlor combined with glyphosate present low control of Raphanus sp. (Table 4), on the contrary of other studies where present a control next to $100 \%$ in weed plants of wide leaf, Amaranthus tuberculatus and Brachiaria platyphylla (Grichar et al., 2009). 
Table 4. Control of Raphanus sp. (\%) in the culture of soybean in function of application of different associations of herbicides in the pre-emergency

\begin{tabular}{lllll}
\hline \multirow{2}{*}{ Treatment } & \multicolumn{4}{c}{ Control of Raphanus sp. (\%) } \\
\cline { 2 - 5 } & 07 DTA & 14 DTA & 21 DTA & 28 DTA \\
\hline Unweeded control & $0 \mathrm{c}$ & $0 \mathrm{~d}$ & $0 \mathrm{c}$ & $0 \mathrm{~d}$ \\
Weeded control & $100 \mathrm{a}$ & $100 \mathrm{a}$ & $100 \mathrm{a}$ & $100 \mathrm{a}$ \\
Gly & $0 \mathrm{c}$ & $0 \mathrm{~d}$ & $0 \mathrm{c}$ & $0 \mathrm{~d}$ \\
Gly + Diu + Sulf & $80 \mathrm{~b}$ & $63 \mathrm{~b}$ & $36 \mathrm{~b}$ & $45 \mathrm{c}$ \\
Gly + Dic & $98 \mathrm{a}$ & $99 \mathrm{a}$ & $98 \mathrm{a}$ & $98 \mathrm{a}$ \\
Gly + Imaz + Flum & $98 \mathrm{a}$ & $99 \mathrm{a}$ & $98 \mathrm{a}$ & $99 \mathrm{a}$ \\
Gly + Flum & $70 \mathrm{~b}$ & $71 \mathrm{~b}$ & $43 \mathrm{~b}$ & $50 \mathrm{~b}$ \\
Gly + 2,4D & $0 \mathrm{c}$ & $0 \mathrm{~d}$ & $0 \mathrm{c}$ & $0 \mathrm{~d}$ \\
Gly + S-met & $0 \mathrm{c}$ & $0 \mathrm{~d}$ & $0 \mathrm{c}$ & $0 \mathrm{~d}$ \\
Glu + Diu + Sulf & $70 \mathrm{~b}$ & $46 \mathrm{c}$ & $36 \mathrm{~b}$ & $0 \mathrm{~d}$ \\
C.V. (\%) & $\mathbf{1 5 . 7 8}$ & $\mathbf{1 5 . 9 1}$ & $\mathbf{1 6 . 5 2}$ & $\mathbf{7 . 5 1}$ \\
\hline
\end{tabular}

Note. * Significant error probability of $0.05 .{ }^{\text {ns }}$ don't significant. Gly: glyphosate, Diu: diuron, Sulf: sulfetrazone, Dic: diclosulan, Imaz: Imazethapyr, Flum: flumioxazim, 2,4-D, S-met: S-metolachlor.

In response to the variable of a thousand grains weight, presented in the infested testimony higher weight when compared with other treatments (Figure 2), possibly this occurs by low number of green beans that the plant can have produced, because of the competition. Therefore, the flow of photosynthates is directly related with the fabrics and their sources, being directed to multiple drains, these process of photosynthates transference is denominated partition (Taiz et al., 2017), therefore, the elevated thousand grains weight is justified by the greater flow of photosynthates demanded by a lower quantity of grains.

In the treatment of 2,4-D associated with glyphosate presented decrease of productivity of grains, however possibly is not the effect of the herbicide that caused this decrease (Braz et al., 2017), but by the effect of the competition of the weed plants that were not controlled (Tables 2 and 3 ).

The treatments that maintained level of control of weed plants over $80 \%$ had satisfactory productivity (Tables 3 and 4), even when in 7 and 14 DTA present phytotoxicity the culture of the soybean (Table 2). Some herbicides as flumioxazin and sulfentrazone present low phytotoxicity the culture and lows don't significands in the soybean grains productivity (Kandel et al., 2018) (Figure 2). To species of weed plants that present resistance or tolerance to the herbicide glyphosate the utilization of herbicides pre-emergents becomes an alterative, reducing the competition of weed plants in the beginning of the season of increasing plants of soybean (Arregui et al., 2006).

It is emphasized that the treatment glyphosate associated with imazethapyr + flumioxazin and diclosulam in grain yield, this because of its control of weed plants and low phytotoxicity, lower than $10 \%$ (Tables 2, 3 and 4). The use of diclosulam associated with glyphosate in the application in pré-emergency demonstrates satisfactory control of dicotyledons, don't influencing in the productivity of soybean grains (Braz et al., 2017). Among all the treatments tested, the unweeded control was the one that had less grain yield, with a reduction of 87 and $86 \%$ less when comparing with the weeded control and the average application of all herbicides. Thus, it is evident that weed control becomes necessary, with some control method to avoid losses in soybean grain yield. 

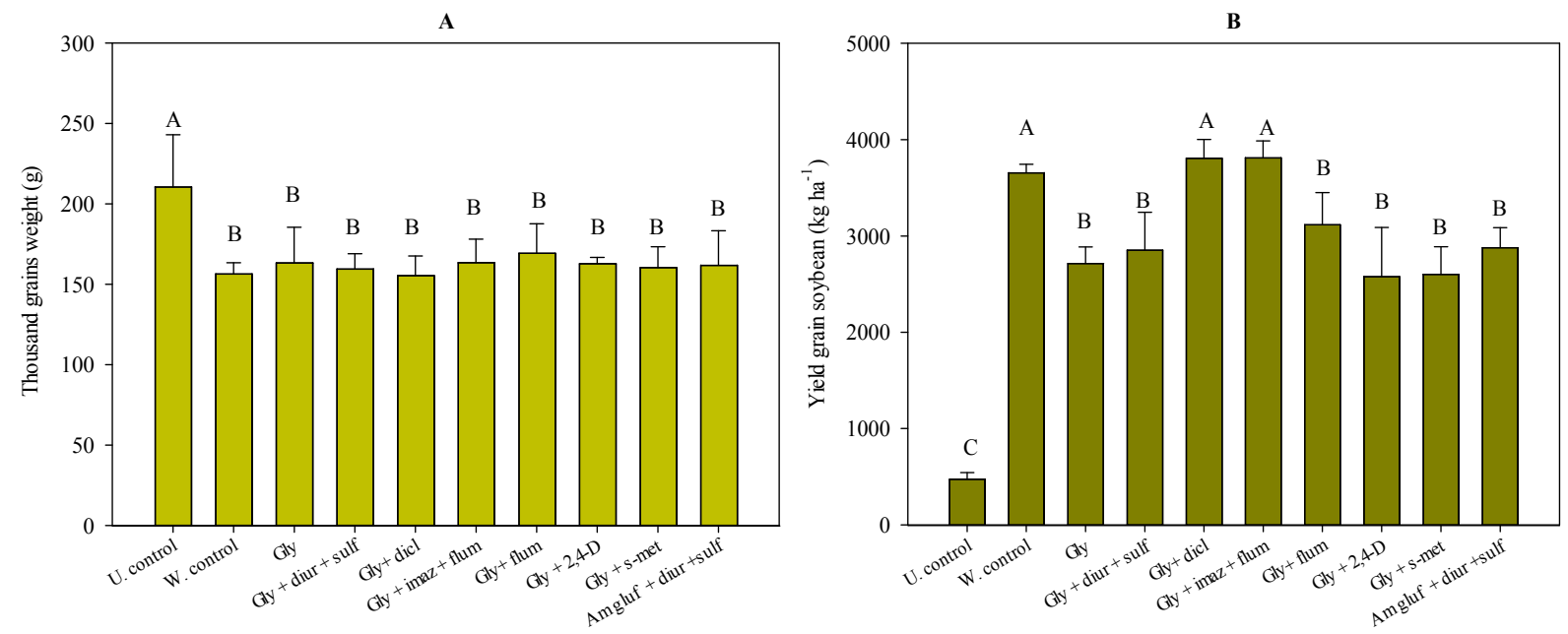

Figure 2. Thousand grains weight (A) and yield grain soybean (B). Vertical columns followed of the same capital letter don't differ between each other by the test Scott Knott, in 5\% of error probability. The vertical bars on the columns represent the standard deviation of the average of four independent biological repetitions. U. control:

unweeded control; W. control: weeded control; Gly: glyphosate; Diur: diuron; Sulf: sulfentrazone; Dicl:

diclosulam; Imaz: imazethapyr; Flum: flumioxazin; S-met: S-metolachlor; Am-gluf: amonio-glufosinato;

$$
\text { 2,4-D: 2,4-D }
$$

\section{Conclusion}

The association of herbicides provided control of weeded plants in the initial stages of the soybean culture. The best treatments were the association of glyphosate with diuron + sulfentrazone, imazethapyr + flumioxazin and S-metalachlor to control of Urochloa plantaginea and diclosulam and imazethapyr + flumioxazin to Raphanus sp., don't influencing in the yield grain of soybean. There was a decrease of 86 and $87 \%$ in the grain yield of the unweeded control for herbicide applications and weeded control, respectively.

\section{References}

Agostinetto, D., Rigoli, P. R., Galon, L., Moraes, P. V. D. de, \& Fontana, L. C. (2009). Relative competitiveness of soybean in simultaneous growth with alexandergrass (Brachiaria plantaginea). Scientia Agraria, 10, 185-190. https://doi.org/10.5380/rsa.v10i3.14473

Agostinetto, D., Vargas, L., Gazziero, D., \& Silva, A. A. (2015). Soja: Do plantio a colheita. In T. Sediyama, F. Silva, \& A. Borém (Eds.), Manejo de plantas daninhas (pp. 234-255). Viçosa-MG: Editora UFV.

Arregui, C. M., Scotta, R., \& Sánchez, D. (2006). Improved weed control with broadleaved herbicides in glyphosate-tolerant soybean (Glycine max). Crop Protection, 25, 653-656. https://doi.org/10.1016/j.cropro. 2005.09.006

Braz, G. B. P., Oliveira, R. S., Zobiole, L. H. S., Rubin, R. S., Voglewede, C., Constantin, J., \& Takano, H. K. (2017). Sumatran fleabane (Conyza sumatrensis) control in no-tillage soybean with diclosulam plus halauxifen-methyl. Weed Technology, 31, 184-192. https://doi.org/10.1017/wet.2016.28

Cechin, J., Vargas, L., Agostinetto, D., Zimmer, V., Pertile, M., \& Garcia, J. R. (2016). Resistence of radish biotypes to iodosulfuron and alternative control. Planta Daninha, 34, 151-160. https://doi.org/10.1590/ S0100-83582016340100016

Dominguez-Valenzuela, J. A., Gherekhloo, J., Fernández-Moreno, P. T., Cruz-Hipolito, H. E., Cruz R. A., Sánchez-González, E., \& Prado R. (2017). First confirmation and characterization of target and non-target site resistance to glyphosate in Palmer amaranth (Amaranthus palmeri) from Mexico. Plant Physiology and Biochemistry, 115, 212-218. https://doi.org/10.1016/j.plaphy.2017.03.022

Fleck, N. G., Bianchi, M. A., Rizzardi, M. A., \& Agostinetto, D. (2006). Raphanus sativus interference on soybean cultivars during crop vegetative period. Planta Daninha, 24, 425-434. https://doi.org/10.1590/ S0100-83582006000300002

Grichar, J., Dotray, P. A., \& Langham, D. R. (2009). Sesame (Sesamum indicum L.) response to preemergence herbicides. Crop Protection, 28, 928-933. https://doi.org/10.1016/j.cropro.2009.07.013 
INMET (Instituto Nacional de Meteorologia). (2018). Retrieved from http://www.inmet.gov.br/portal/index.php? $\mathrm{r}=$ tempo2/mapasPrecipitacao

Jaremtchuk, C., Constantin, J., Júnior, R., Biffe, D., Alonso, D., \& Arantes, J. (2008). Effect of burndown management on desiccation speed, initial weed emergence, development and yield of soybean. Acta Scientiarum Agronomy, 30, 449-455.

Kandel, Y., Mueller, D., Legleiter, T., Johnson, W., Young, B., \& Wise, K. (2018). Impact of fluopyram fungicide and preemergence herbicides on soybean injury, population, sudden death syndrome, and yield. Crop Protection, 106, 103-109. https://doi.org/10.1016/j.cropro.2017.12.009

Li, M., Yu, Q., Han, H., Aiuba, M., \& Powlesa, S. (2013). ALS herbicide resistancemutations in Raphanus raphanistrum: Evaluation of pleiotropic effects on vegetative growth and ALS activity. Research Article, 6, 689-695. https://doi.org/10.1002/ps.3419

Liu, K. (2016). Soybean: Overview. Encyclopedia of Food Grains, 2, 228-236.

Miransari, M. (2016). Soybean, Protein, and Oil Production Under Stress. In M. Miransari (Ed.), Environmental Stresses in Soybean Production (2nd ed.). AbtinBerkeh Scientific Ltd. Company, Isfahan, Iran. https://doi.org/10.1016/B978-0-12-801535-3.00001-2

Nonemacher, F., Galon, L., Santin, C. O., Forte, C. T., Fiabane, R, C., Winter, F, L., .. Perin, R. R. K. (2017). Herbicide association applied to control weeds in glyphosate-resistant soybean. Revista Brasileira de Herbicidas, 16, 152-162. https://doi.org/10.7824/rbh.v16i2.529

Rodrigues, B. N., \& Almeida, F. R. (2011). Guide to herbicides (5th ed., p. 697). Londrina: Edição dos Autores.

ROLAS (Rede Oficial de Laboratórios de Análise de Solo e de Tecido Vegetal). (2016). Manual de adubação e calagem para os estados do Rio Grande do Sul e Santa Catarina (Vol. 11, p. 376). Porto Alegre: Sociedade Brasileira de Ciência do Solo.

SBCPD (Sociedade Brasileira da Ciência das Plantas Daninhas). (1995). Procedimentos para instalação, avaliação e análise de experimentos com herbicidas (p. 42). Londrina: SBCPD.

Singh, V., Burgos, N., Singh, S., Abugho, S., Earnest, L., Gbur, E., \& Scott, R. (2016). Herbicide and winter flood treatments for controlling volunteer rice off-season. Crop Protection, 79, 87-96. https://doi.org/ 10.1016/j.cropro.2015.10.001

Soil Survey Staff. (2014). Keys to Soil Taxonomy (12th ed.). USDA, Natural Resources Conservation Service: Washington DC.

Taiz, L., Zeiger, E., Moller, I. M., \& Murphy, A. (2017). Plant Physiology and Development (6th ed.). Porto Alegre: Artmed.

USDA. (2018). Foreign Agricultural Service: World Soybean Production, Consumption, and Stocks. Retrieved from https://apps.fas.usda.gov/psdonline/app/index.html\#/app/compositeViz

Westwood, J. H., Charudattan, R., Duke, S. O., Fennimore, S. A., Marrone, P. Slaughter, D. C., ... Zollinger, R. (2018). Weed Management in 2050: Perspectives on the Future of Weed Science. Weed Science, 66, 275-285. https://doi.org/10.1017/wsc.2017.78

\section{Copyrights}

Copyright for this article is retained by the author(s), with first publication rights granted to the journal.

This is an open-access article distributed under the terms and conditions of the Creative Commons Attribution license (http://creativecommons.org/licenses/by/4.0/). 